\title{
Vanishing Taxus baccata L. Due to Unsustainable Exploitation and Climate Change in West Kameng and Tawang Districts of Arunachal Pradesh
}

\author{
Gibji Nimasow ${ }^{1, *}$, Oyi Dai Nimasow ${ }^{2}$, Gendan Tsering ${ }^{1}$ \\ ${ }^{1}$ Department of Geography, Rajiv Gandhi University, Itanagar, Arunachal Pradesh, India \\ ${ }^{2}$ Department of Botany, Rajiv Gandhi University, Itanagar, Arunachal Pradesh, India
}

Email address:

gibji26@yahoo.co.in (G. Nimasow), oyidai07@yahoo.com (O. D. Nimasow), gendantsering@gmail.com (G. Tsering)

\section{To cite this article:}

Gibji Nimasow, Oyi Dai Nimasow, Gendan Tsering. Vanishing Taxus baccata L. Due to Unsustainable Exploitation and Climate Change in West Kameng and Tawang Districts of Arunachal Pradesh. Earth Sciences. Special Issue: Conservation of Taxus Baccata Linn (Yew).

Vol. 4, No. 3-1, 2015, pp. 11-18. doi: 10.11648/j.earth.s.2015040301.12

\begin{abstract}
Taxus baccata, a small to medium sized tree is valuable for extraction of taxol which is used in preparation of anti-cancer drugs (breast and ovarian cancer), kaposi's sarcoma (an AIDS related cancer) and over 20 such other indications. The plant is rare, endangered and listed in Appendix II of Convention on International Trade in Endangered Species of wild Fauna and Flora (CITES) showing widespread decline in population and increasing fragmentation worldwide. Around 2 to 3 million $\mathrm{kg}$ of biomass is harvested annually where as the sustainable rate of harvesting is estimated to be 0.6 million $\mathrm{kg}$ per year. It grows at an altitudinal range of 1500 to $3000 \mathrm{~m}$ throughout Arunachal Pradesh in Bomdila, Shergaon, Eagle Nest, Dirang, Thungri, Tawang, Mago and Zemithang in West Kameng and Tawang Districts, Tale Valley (few trees only) of Lower Subansiri, Anini, Mayodiya in Dibang Valley district, Mechuka in West Siang and Melinja and Hot spring areas of Lohit District. Random linear transacts in West Kameng and Tawang districts of Arunachal Pradesh recorded a total of 265 Taxus plants. Out of which, 130 are live trees and 135 are dead plants. In the absence of standard lopping technique and non-existence of any regulatory mechanisms for sustainable harvest, the leaves were pruned mercilessly to the extent that plant could not withstand to survive. Moreover, the pressing demands and associated lucrative price lured middlemen and villagers to plunder this scarce resource pushing it to the extreme limits of disappearance. The interaction with the villagers revealed that about 100 trucks of Taxus leaves were supplied each from villages of the area. Thus, around 1000 full grown trees have been completely pruned from the area before the ban imposed by the Supreme Court of India in 1996. The results point towards unsustainable and unorganized way of exploitation of the plant in the eastern Himalayas during the recent past. Although Taxus baccata is known to be tolerant to shade, high temperature and low moisture stress but the sudden and unlikely changes in climatic variables may cause both positive and negative impacts on the future of the plant. Hence, the paper attempts to discuss the impact of unsustainable exploitation as well as climate change and suggest suitable strategies for conservation and modeling of this rare and endangered medicinal plant in the study area.
\end{abstract}

Keywords: Taxus baccata, Taxol, Unsustainable, Exploitation, Climate Change

\section{Introduction}

Taxus baccata is valuable for taxol or paclitaxel extraction [1] used in the preparation of anti-cancer drugs, in addition to other medical uses in Ayurveda and Tibetan medicine [2]. The non-cancer uses are for coating of stents (anti-angiogenesis), alzheimer, multiple-sclerosis and polycystic kidney disease [3]. The bark paste is applied as a plaster on fractured bone, also applied on the forehead for relief from headache [4] and the leave and bark extracts are also used for the treatment of bronchitis, asthma, poisonous insect bites and also as an aphrodisiac [5]. The Tolchha and Marcha Bhotia communities and other traditional societies of buffer zone of Nanda Devi Biosphere in Garhwal Himalaya have been collecting the bark of $T$. baccata mainly for making traditional tea and for curing cold and cough besides using it for thatching, wood carving, house construction and honey-bee shelter [6]. It is found in the temperate and least disturbed forest due to inaccessibility and unsuitability for other land use [7]. The tree has spreading branchlets and leaves arranged in two whorls which are 2.5 to 
$3.5 \mathrm{~cm}$ long and linear. They are glossy green above and pale beneath which distinguishes the tree from Cephalotaxus and Tsuga which have leave undersurface white. Fruits are 0.7 to 1 $\mathrm{cm}$ long with succulent bright red disc that covers the blackish olive green seed. Taxus flowers during March to May and seeds are produced during October to November. Natural regeneration is more pronounced under broken canopy [8]. Once the pacific yew had been the only source of taxol, but in 1995 Asian Yew (Taxus wallichiana Zucc.) a closely related plant that grows in Himalayas is listed in Appendix II of CITES [9]. Taxol was first isolated from the bark of Taxus brevifolia [10], but in India and other parts of the world pharmaceutical companies have succeeded in isolating it from the leaves [11]. Although all 11 species of Taxus make taxol, the natural stands of these trees are often small and remote [12]. Moreover, only 0.01 to $0.03 \%$ of the dry phloem weight is taxol, yet as much as $2 \mathrm{~g}$ of purified taxol is required for a full regimen of anti-tumor treatment [13]. It is reported that a 20 year old tree can yield up to $30 \mathrm{~kg}$ of leaves and $5 \mathrm{~kg}$ of barks which in turn produce 4 gm of taxol priced at Rs. 3 lakhs at a very conservative estimate [7]. The worldwide demand of the taxol is $800-1000 \mathrm{~kg}$ annually [3]. The estimated $30,000 \mathrm{~kg}$ of the biomass of T. baccata is needed to produce $1 \mathrm{~kg}$ of the paclitaxel. West Kameng and Tawang districts of Arunachal Pradesh have been identified as one of the important region where Himalayan yew grows naturally [14]. But, the plant has been subjected to large scale exploitation pushing it to the limit of extinction during the past decades. Therefore, the paper attempts to discuss the unsustainable exploitation and impact of climate change on this important medicinal plant and suggest desirable measures for its conservation and regeneration.

\section{Study Area}

West Kameng and Tawang district are parts of Eastern Himalayan Biodiversity Hotspot that is rich in both floral and faunal diversity but its ecosystem has been considered fragile and ranked 200 ecologically important region of the world. The study area lies approximately between $91^{\circ} 30^{\prime}$ to $92^{\circ} 45^{\prime}$ East longitudes and $26^{\circ} 54^{\prime}$ to $28^{\circ} 01^{\prime}$ North latitudes (Figure $1 \mathrm{a} \& \mathrm{~b})$. The districts share international border with Tibet and Bhutan. The topography is mostly mountainous and its greater part falls within the higher mountain zone, consisting of tangled snow-clad peaks and valleys. The districts have very distinct physiographic setting based on specific lithology. Bichom, Tenga, Dirang Chu, Tawang Chu and Nyamjang Chu are the main rivers. On the basis of structural and compositional characteristics, the vegetation of the district is broadly classified into tropical semi-evergreen, temperate forest and sub-alpine and alpine forest. The temperate forests are further classified into broad leaved forest $(2750-3000 \mathrm{~m})$ and Temperate coniferous and broad leaved forest (3000$3500 \mathrm{~m}$ ) while the sub-alpine and alpine forests includes Rhododendron scrub lands $(4000-4300 \mathrm{~m})$, Dwarf Rhododendron meadows $(4200-4600 \mathrm{~m})$ and High altitude grassy meadows $(4350-5250 \mathrm{~m})$. On an average the areas receives $1698 \mathrm{~mm}$ annual rainfall and mean maximum and minimum monthly temperature of $21.66^{\circ} \mathrm{C}$ and $-0.65^{\circ} \mathrm{C}$. The average annual relative humidity ranges from $66.21 \%$ to $79.35 \%$. West Kameng has a total population of 74,599 (Census 2001) and inhabited by Monpa, Miji (Sajalong), Sherdukpen, Aka (Hrusso), and Bugun (Khowa) tribes. Tawang district has a total population of 49,977 and inhabited by Monpa tribes.

\section{Methodology}

Intensive transact surveys with the help of local experts, hunters, semi-nomadic herders, etc. were conducted in a random manner to locate the Taxus trees. Information was also collected through informal interaction with the villagers. Global Positioning System (GPS) was used to record the latitude, longitude and altitude of Taxus baccata. At each GPS location of Taxus tree other information such as soil temperature, soil $\mathrm{pH}$ and soil moisture content were recorded with the help of soil thermometer, $\mathrm{pH}$ meter and digital soil moisture meter. Soil samples were also collected for soil texture analysis in the laboratory with the help of hydrometer. Conservation strategies through awareness campaign, workshops, poster display, pamphlets, calendar, talks, etc. were carried out in the areas where plant is located and extensive exploitation is observed. A detailed literature survey was conducted to gather information related to Taxus baccata, environmental factors and climate change in different parts of the world. The results of the present study has been compared and discussed with the findings of work done in other parts of the world to derive suitable conclusions.

\section{Results and Discussions}

\subsection{Field Results}

Linear transacts were laid in the vicinity of the localities like Domkho, Morshing, Sanglem, Khelang, Mandala-phudung, Dirang, Bomdila, New Bomdila and Palizi-Ramda of West Kameng district where a total of 145 Taxus plants were located with Global Positioning System (GPS). Out of which 105 plants were dead and only 38 plants were live. Among the 38 live plants, 20 are seedlings, 14 are saplings and 4 are full grown trees explicitly indicating very poor natural regeneration and unsustainable exploitation of the species. Another random linear transact laid in the localities of Jang, Chaagar, Hot spring, Mukto, Nangsam, Narum Dzong, Pangi, Thingbu, Sangdongmetse and Zemithang of Tawang district recorded a total of 118 Taxus plants. Out of which 19 plants were dead and 99 plants were live. Among the 99 live plants 10 are seedlings, 30 are saplings and 59 are full grown trees. However, most of the plants appear unhealthy and recovering with regenerated new leaves. 


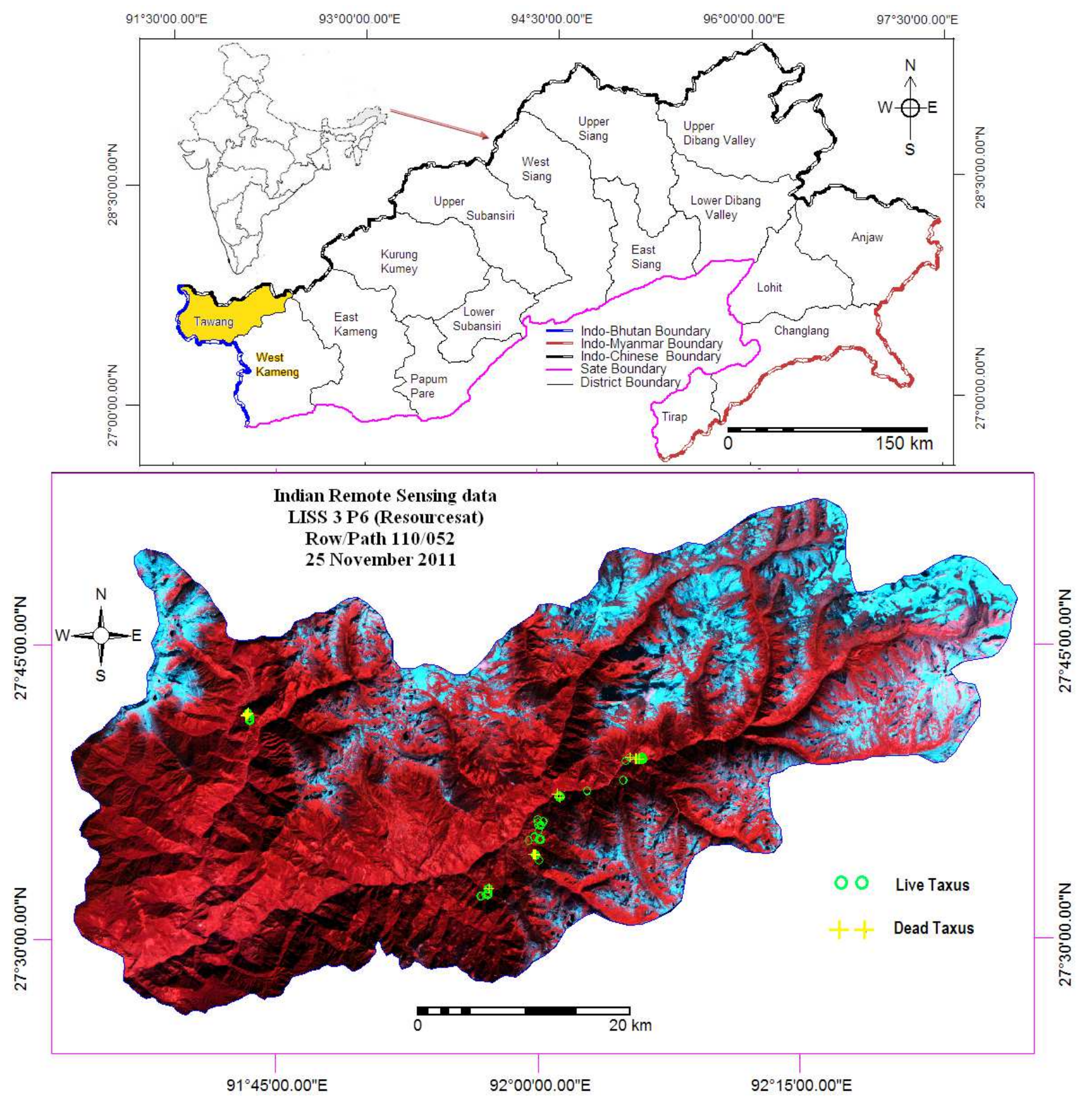

Figure 1 (a). Location map of Tawang district.

Therefore, the probability of plants becoming healthy with the passage of time is uncertain keeping in view the anthropogenic influences, livestock grazing and climate change. The plants are mostly concentrated within the altitudinal range of 1800 to $3000 \mathrm{~m}$. Only in case of Palizi-Ramda village, it was located in between 1000 to 1500 $\mathrm{m}$ altitude and few scattered plants are also located above $3000 \mathrm{~m}$ near Mandala top. This indicates much localized distribution of the species, limited by altitudinal range and other favourable conditions which certainly have its implications on the plant regeneration. Litter decomposed black soil, brown soil, blackish brown and sandy soils with small pebbles are the soil types observed during the field survey. Most of the soil samples collected from the live and death Taxus plants have silt loam texture, however some of the samples have sandy and clayey texture with presence of organic matter and litter. The soil temperature ranges from $1^{\circ}$ $\mathrm{C}$ to $23^{\circ} \mathrm{C}$. The $\mathrm{pH}$ value of live as well as death Taxus plants varies from 4.8 to 7 and the soil moisture varies from $10 \%$ to $71 \%$. Taxus has been reported to grow well in any soil but it favours calcareous soils in N. Europe. The growth is best in deep moist sandy loams with well drained clays and worst on dry, rocky and sandy soils. Keeping in view the importance and conservation of the plant an awareness workshop was organized in the Domkho village of West Kameng district and Yuthembu village near Jang of Tawang district. During the 
workshop the villagers were educated about the importance of the tree, its vulnerability and present condition at global, national and local levels. They were also encouraged to protect and regenerate the plant in sacred areas, kitchen gardens and during important ceremonies like marriage, death ceremony and anniversaries.

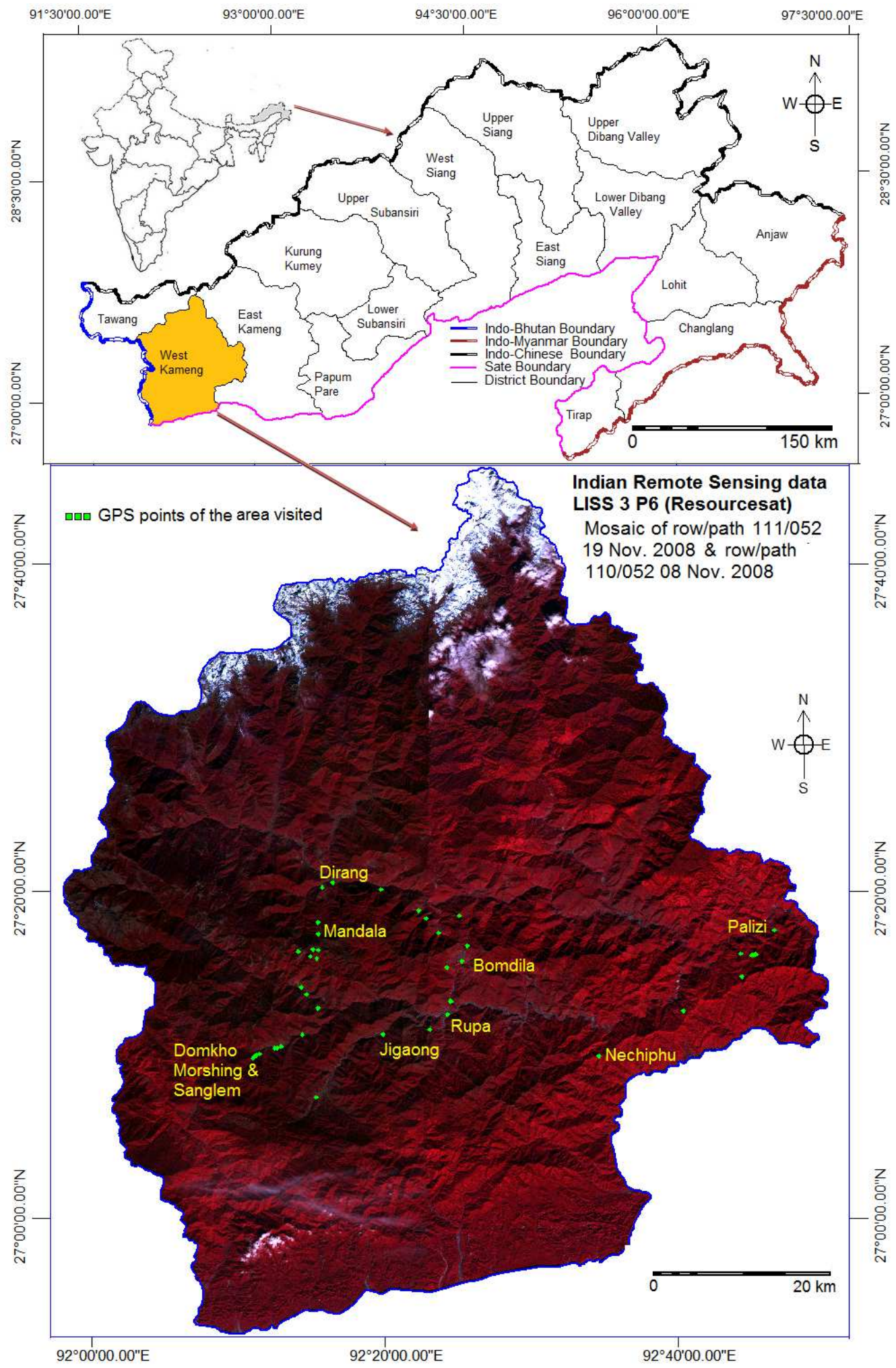

Figure 1(b). Location map of West Kameng district.

\subsection{Impact of Unsustainable Exploitation on the Plant}

Large scale exploitation of Taxus plants has taken place during 1990s in West Kameng and Tawang districts of Arunachal Pradesh. The interaction with village elders, herdsmen, hunters, local body members, etc. reported that Taxus (locally known as Tesiang) was found abundantly in 
nearby forest surrounding the villages. But, after the large scale supply of leaves, it is now not found within 8 to $10 \mathrm{~km}$ radius from the villages. The linear transacts in the deep forests around the villages revealed many dead and few live Taxus trees along the steep slopes. The complete extraction of leaves resulted in the dead of the plants. In the absence of standard lopping method and any regulatory mechanisms for sustainable harvest, the leaves were pruned mercilessly to the extent that plant could not withstand to survive. Moreover, the pressing demands and associated lucrative price lured middlemen and villagers to plunder this scarce resource pushing it to the extreme limits of disappearance. The complete dryness of all harvested plants in the area, speaks a volume of unscrupulous way of exploitation for commercial purpose. The villagers reported that about 70 to 80 trucks of Taxus leaves were supplied from different villages of the area. One truck of the Taxus would need at least 30 fully grown trees to be completely pruned. Thus, around 9600 full grown trees have been completely destroyed from the area. They expressed their ignorance about the importance and vulnerability of the tree. Although, some portion of the canopy were left for sustainable re-growth of plant, but eventually those leftovers were also lopped down due to the high demands. Surprisingly, even the seedlings or the young plants are conspicuous by their absence in the vicinity of dried up trees. This confirms the reported poor regeneration, germination and survival rates of the plant [15]. However, there could be many reasons attributed to this phenomenon. Firstly, the dense forest with thick undergrowth may have prevented the growth of seedlings as the natural regeneration is reported well in broken canopy. Second possible reason may be the browsing of the wild animals, cattle and fowls. Thirdly, the illegal trade also cannot be ruled out. A clandestine trading in the species is taking place in some states where young saplings raised by the locals are being collected by the agents and sold abroad through an established network [16]. In 2001 Assam forest officials at Tezpur seized 220 bags of Taxus leaves loaded in three trucks from Arunachal Pradesh which strongly suggest deeply entrenched nexus of politicians, contractors and forest officials operating in Arunachal Pradesh [17]. A local firm in West Kameng District - M/S Arunachal Pradesh Herbal Company Private Ltd., had entered a lease agreement with the state forest department in November, 2001 to collect Taxus leaves from the forests in West Kameng and Tawang districts for 15 Years.

The Taxus leaves in earlier times were fed to the cattle, especially to the Yak as it is believed that the leaves of Taxus keep their cattle healthy and fetch good quality milk and milk products. According to the villagers, another factor for drying of the plants is due to extraction of leaves by the Brokpas (a transhumant tribe) during a particular season when there is lack of fodder in the forest. The practice of transhumance pastoralism also demands pasture lands (Brok) for the Yak and other cattle in different altitudes which is the major cause of forest degradation in general and loss of valuable temperate species in particular. The increasing demand of pasture land is met by clearing forest and setting fire into it which sometimes causes uncontrollable forest fire. Fire is also set in the forest during dry season to burn undergrowth or ground cover of pine leaves which help in the growth of tender grasses for cattle. It reveals yet another dimension of the prevailing anthropogenic threat to this important plant from within the region for fodder and pastures. In the context of rapid changes owing to such forest losses, vegetation cover and species population is expected to decrease over small spatial scale [18]. The excessive species loss could also lead to collapse of the ecosystem [19]. In fact, habitat fragmentation which is a typical consequence of human activities negatively impacts yew pollination and fitness because formation of viable seeds requires that individuals of both sexes co-exist on the landscape. Land use changes are also likely to have contributed to shrinking yew habitat, through logging of old-growth stands, often in combination with grazing and burning [20]. Such activities have transformed the forest landscape and affected vegetation dynamics, especially of shade-tolerant and late-successional species such as yew [21].

There was no rules or instructions and standardize method of exploitation from the Government's side. Wherever, the Taxus trees are found, irrespective of its size, cut the leaves and sell off was the order of the day. However, the profits are being garnered mainly by the drug manufacturers and middlemen, to the neglect of the local people [22]. Although this slow growing plant produces resistant hard wood, the study shows that it is very delicate to survive without adequate canopy unlike other coniferous trees. The extensive and indiscriminate exploitation of Taxus baccata has posed a serious threat to this important Himalayan tree [23, 24]. Degradation of old populations and low regeneration in its natural habitat are the main problems in the conservation of Taxus baccata. Low regeneration and recruitment of this species are because of grazing of browsing animals, chilling injury, direct sunlight and fire, which are common in the Himalayan region [25]. Although few saplings and seedlings were found in these areas, but the number is very less and sparsely scattered and isolated. Some of the villagers have ventured to cultivate Taxus plants in the farmyards but, the rate and scale is very insignificant to compensate the irreparable loss met to this resource. A villager named Pema Tashi from the Morsing village is growing Taxus plants in his kitchen garden, horticulture garden and along the fences of his field. Every year he collects Taxus seeds and grows it in a small nursery and transplants it to other suitable areas. As per his practical experience he reported that there is very poor success rate of the Taxus seeds and seedlings. He took up this challenging task by his own inspiration and by the solace his family received from the Taxus plant. During the time when his family members succumbed to tough time due to financial crisis, the trade on Taxus was in full swing in the area. He too joined the extraction and supply of the Taxus leaves. He sold the rawTaxus leaves@Rs.3 perkg and the dried leaves@of Rs. 27 per kg. Workshops at the grass root level is an effective means of educating the villagers which facilitates direct and close interaction with them. At the same time it is very difficult task to reach each and every village, especially in the 
area like Arunachal Pradesh. Taxus do not grow under the dense canopy and in the areas which are easily accessible to browsing animals. The degraded forests inaccessible to animals, fenced gardens and religious places like temple premises are the suitable areas for regeneration of Taxus.

\subsection{Impact of Climate Change on the Plant}

Taxus baccata maintains a stress tolerant life strategy in the wild as it is known to be tolerant to shade, full sun, soil, slope and fungal diseases. This stress enduring capacity reveals that the growth and survival of the plant is highly governed by the environmental factors [26]. Topography of an area creates conditions that favour survival of Taxus baccata [27]. Taxus was mainly found at 1,000-1,600 m elevation on mesic exposures (north and west) and intermediate slopes of 30-60\% [20]. As Taxus is the most shade tolerant tree it survives under the low sunlight conditions. In Europe it survives even below its own formidable shade [28]. It is capable of producing viable seeds in $<5 \%$ sunlight but growth is better with increasing light. Natural regeneration is more pronounced under broken canopy [8]. The plants located under dense canopy of higher plants appear unhealthy with very less leaf density while plants under broken canopy with increasing light in open conditions appear healthy. However, growth is generally fastest under certain amount of residual shades. This is due to more favourable microclimate under shade and the reduced levels of competition from other vegetation that yew would face in fully open conditions [29]. It has been reported that the leaves and buds can resist frost damage in N. Europe down to -21 to $-35^{\circ} \mathrm{C}$. In Britain damage starts at $-13.4^{\circ} \mathrm{C}$ in midwinter [30]. Resistance to high temperatures is comparatively high but can be problematic. The potential susceptibility of yew to high temperatures is indicated by the recommendation in the UK that plastic tree shelters should not be used for Taxus as overheating can occur, despite the shelters being suitable for most other tree species. The optimum temperature range for photosynthesis is between $14-25^{\circ} \mathrm{C}$ higher than in other species of gymnosperm. Although photosynthesis is possible under a wide range of light and temperature conditions, it is sensitive to sudden change of light and exposure to the sun. Sudden removal of other trees around a Taxus tree can lead to extensive damage or even death. This should be borne in mind while opening up a canopy to increase the regeneration of Taxus. The stands containing Taxus should be thinned by no more than $30 \%$ at any one time [31]. The best performance of Taxus is seen under high rainfall. In England 80\% of Taxus woodlands occur in areas of maximum rainfall $>1000 \mathrm{~mm}$ year. High humidity is normally a requirement for the best growth of yew although around $50 \%$ of needles can be killed in a year by fungal attack due to high humidity. At the other end of the moisture scale Taxus is very tolerant of drought. In compare to other gymnosperms Taxus leaves have a high N, P, K, Mn, Zn, B and Mo content as well as low Al, Si and Fe content. The roots of Taxus have Arbuscular mycorrhiza associations. As the level of atmospheric pollution has increased from a natural background to many hundreds kg per hectare per year [32], much of this $\mathrm{N}$ pollution is in non-organic forms. Arbuscular mycorrhizas have better access to non-organic sources of $\mathrm{N}$ and $\mathrm{P}$ [33] and so yew may have better access to this extra nitrogen. It is also highly resistant to $\mathrm{SO}^{2}$ though higher concentrations may damage the needles. A potential problem for yew is that being dioecious, pollination may fail if the population becomes sufficiently fragmented that females receive insufficient pollen. A compounding factor is that of sex ratios in yew. If is due to increasing temperature or reduced rainfall or humidity this has important implications for climate change. The time taken for yew trees to reach sexual maturity (when they start producing viable seeds) is slow around 30-35 years in open trees and up to 70-120 years in dense stands. This raises question as to whether environmental changes induced by climate change will happen too quickly for a stress tolerant, slow growing trees such as yew to respond. Despite its poisonous properties, yew is very susceptible to browsing and bark stripping by rabbits, hares, deer and domestic animals [34]. However, yew is tolerant of repeated pruning of the foliage and is usually able to continue growth even under severe browsing pressure (although repeated very heavy grazing to ground level can kill yew). Successful regeneration of Taxus is often best below shrubs (especially those that are thorny and or have fleshy fruits). These shrubs maintain a suitable moist microclimate, give protection from herbivores and the fleshy fruits attract birds that defecate or drop Taxus seeds into the shade below $[35,36]$. Under elevated Carbon dioxide in low light sites biomass production of yew increased but not in high light conditions. Yew trees are likely to be at advantage at higher carbon dioxide concentrations but may lose their advantage in higher light levels. The germination, recruitment and survival of Taxus baccata is likely to improve in deep shade conditions such as under a dense tree canopy with the rise in carbon concentration. On the negative side higher temperature and lower rainfall may reduce growth and survival, particularly of older trees.

\section{Conclusions}

The rampant exploitation of the Taxus has occurred in many areas of West Kameng and Tawang Districts of Arunachal Pradesh during the 1990s. Since no regulatory mechanism and standardized harvesting techniques were adopted, the trees dried up once its leaves were harvested. This has pushed this valuable resource to the extreme limit of extinction from the area. Consequently, Taxus in a natural stand is not available in the study area. However, In Zemithang area, a sacred grove or preserved forest area has about 30-40 Taxus trees in natural stand. There are no systematic approaches made in order to regenerate this species through the active participation of the communities and the people themselves are also not coming forward to take up such challenges. No doubt, the State Research Institute (SFRI), Itanagar and National Medicinal Plant Board have started nursery and propagation trial project near Bomdila. But, the nurseries appear to be lack of maintenance and regular care as there is only one caretaker in 
the nursery. Lack of proper treatment led to many dried saplings of Taxus in the nursery. Moreover, there is no awareness among the people about the importance of the tree and people rarely visits and collect Taxus saplings from the nursery for propagation in their areas. Thus, the findings shows adverse effects of exploitation on Taxus plant, very poor natural regeneration of plant, localized natural growth, no tangible efforts to regenerate the plants have pushed this important resource to extreme limit of extinction. The regeneration of the plant involves risk and uncertainty to the villagers. Besides, there is need of special care and additional financial involvement in providing proper fencing to protect the plant from browsing animals. Therefore, there is an urgent need of concrete steps for conservation and regeneration of this vanishing valuable resource. This can be achieved through community awareness, participation, suitable propagation techniques, in-situ and ex-situ trials, demonstration, financial and infrastructural assistance. Since the growth of plant and its survival rate are very low, the regeneration of the plant involves risk and uncertainty to the villagers. Moreover, the regeneration also needs proper protection (fencing) against browsing animals feeding on the plants. Because of all these practicalities the farmers are reluctant to regenerate Taxus plants by their own even if it has great demand in the pharmaceutical industries. Therefore, more focus is needed on the financial assistance and remuneration to the growers to ensure large scale participation. More importantly, there is also a need of regulatory mechanism and standardized harvesting techniques for the sustainable use of this resource. Yew can tolerate fairly high temperatures and higher carbon dioxide levels may benefit the yew but associated lower rainfall, lower humidity and abnormally high temperatures may prove detrimental. Most importantly the predicted changes may just be too fast to cope with for a long lived tree like yew. But, there are models suggesting little changes in the Taxus distribution under climate change scenarios [37]. Hence, there is a need for proper ecological modeling to investigate the positive and negative effect of climate change on Taxus baccata.

\section{Acknowledgements}

The authors are thankful to the villagers of Tawang and West Kameng district of Arunachal Pradesh (India) for the cooperation and participation in the project works. We are also grateful to the University Grants Commission, New Delhi, Ashoka Trust for Research in Ecology and the Environment, Darjeeling and Critical Ecosystem Partnership Fund for funding major projects on the phytogeographic survey and conservation efforts of Taxus baccata Linn.

\section{References}

[1] D. Phillips, D. B. Dwyer and Dabur Research Foundation, "Sustainable harvesting of Himalayan yews," in Medicinal plant trade in Europe: conservation and supply, TRAFFIC EUROPE, Eds. Cambridge: Europe, 1998, pp. 147-154.
[2] Z. Saqib, R. N. Malik, and S. Z. Husain, "Modeling potential distribution of Taxus wallichiana in Palas Valley, Pakistan." Pak. J. Bot., vol. 38(3), pp. 539-542, 2006.

[3] S. I. Cameron and R. F. Smith, "In Bringing 'Blue Sky Biology' Down to Earth: Linking Natural Products Research with Commercialization," in Proc. 29th Annual Meeting of the Plant Growth Regulation Society of America, N. S. Halifax, Eds., 2002, pp. 31-39.

[4] R. D. Gaur, "Flora of the District Garhwal North West Himalaya with Ethnobotanical Notes," Trans Media, Srinagar (Garhwal) 1999, p. 48.

[5] S. M. Beckstrom-Sternberg and J. A. Duke, "International Yew Resource Conference," Berkeley, USA, 1993, p. 3.

[6] R. K. Maikhuri, S. Nautiyal and K. S. Rao, "Role of medicinal plants in traditional health care system: A case study from Nanda Devi Biosphere Reserve," Curr. Sci., vol. 75, pp. 152-157, 1998.

[7] G. P. Shukla, K. Rao and K. Haridasan, "Taxus baccata in Arunachal Pradesh," Arunachal Forest News, vol. 12(1), pp. $1-7,1994$.

[8] K. Haridasan, A. Sarma, and L. R. Bhuyan, "Gymnosperm Diversity in Arunachal Pradesh," Arunachal Forest News, Bio-Diversity Special, vol. 19, pp. 32-42, 2001.

[9] U. Schippmann, "Medicinal plants significant trade study," CITES Project S-109, German Federal Agency for Nature Conservation, Bonn, 2001.

[10] M. C. Wani, H. L. Taylor, M. E. Wall, P. Cogon and A. T. Mcphail, "Plant antitumor agents. VI. Isolation and structure of taxol, a novel antileukemic and antitumor agent from Taxus brevifolia," J. Am. Chem. Soc., vol. 93, pp. 1325-1327, 1976.

[11] A. Purohit, R. K. Maikhuri, K. S. Rao and S. Nautiyal, "Impact of bark removal on survival of Taxus baccata L. (Himalayan yew) in Nanda Devi Biosphere Reserve, Garhwal Himalaya, India," Curr. Sci., vol. 81(5), pp. 586-590, 2001.

[12] A. Stierle, G. Strobel and D. Stierle, "Taxol and taxane production by Taxomyces andreanae, an endophytic funguan of Pacific Yew," Sci., vol. 260, pp. 214-222, 1993.

[13] J. Ge, W. Ping and D. Zhou, "Characterization of a New Species of Taxol-producing Fungus," Nature Sci., vol. 2, pp. 85-88, 2004.

[14] M. K. Mishra and R. Dutta, "Draft report, Base Line Information on Medicinal Plants Conservation and Sustainable Utilization," 2003, pp. 1-49.

[15] B. S. Beniwal and K. Haridasan, "Natural Distribution and status of regeneration of Gymnosperms in Arunachal Pradesh," Ind. Forester, vol. 118, pp. 96-101, 1992.

[16] P. Gupta, 1994, "Losing Naturally: clandestine trading in a medicinal plant costs India dearly," Sunday, 6-12 February, 1994.

[17] Grassroots Options, "North East India's first magazine on people environment and Development," Monsoon-Autumn Issue, 2002.

[18] A. Agarwal, and G. Srivastava, "Forest destruction in Eastern Himalayas," Curr. Sci., vol. 94(1), pp. 8, 2008. 
[19] R. Kanade, M. Tadwalkar, C. Kushalappa and A. Patwardhan, "Vegetation composition and woody species diversity at Chamoli NP, North Western Ghats, India," Curr. Sci., vol. 95(5), pp. 637-646, 2008.

[20] G. Piovesan, E. P. Saba, F. Biondi, A. Alessandrini, A. Filippo and B. Schirone, "Population ecology of yew (Taxus baccata L.) In the Central Apennines: spatial patterns and their relevance for conservation strategies," Plant Ecol., DOI 10.1007/s11258-009-9596-1, 2009.

[21] C. Kwit, C. C. Horvitz and W. J. Platt, "Conserving slow-growing, long-lived tree species: input from the demography of a rare understory conifer, Taxus floridana," Conserv. Biol., vol. 18, pp. 432-443, 2004.

[22] A. Khanna, "Himalayan Yew to fight Cancer," Down to Earth, vol. 2, p. 41, 1994.

[23] S. K. Nandi, L. M. S. Palni and H. C. Rikhari, "Chemical induction of adventitious root formation in Taxus baccata cuttings," Plant Growth Regulation, vol. 19, pp. 117-122, 2006.

[24] R. P. Khali, Ecological studies on Taxus baccata Linn. In relation to regeneration and conservation, Ph D Thesis, FRI Deemed University, Dehradun, 2001.

[25] A. Purohit, R. K. Maikhuri, K. S. Rao and S. Nautiyal, "Impact of bark removal on survival of Taxus baccata L. (Himalayan yew) in Nanda Devi Biosphere Reserve, Garhwal Himalaya, India," Curr. Sci., vol. 81(5), pp. 586-590, 2001.

[26] J. C. Svenning and F. Skov, "The relative roles of environment and history as controls of tree species composition and richness in Europe," J. Biogeo., vol. 32, pp. 1019 - 1033, 2005.

[27] H. C. Rikhari, L. M. S. Palni, A. S. Sharma and S. K. Nandi, "Himalayan yew: Stand structure, canopy damage, regeneration and conservation strategy," Environ. Conser., vol. 25(4), pp. 334-341, 1998.

[28] G. Iszkulo, A. Boratynski, Y. Didukh, K. Romaschenko and N. Pryazhko, "Changes of population structure of Taxus baccata $\mathrm{L}$. during 25 years in protected area (Carpathians, Western Ukraine)," Polish J. Ecol., vol. 53, pp. 13-23, 2005.

[29] G. Iszkulo, and A. Boratynski, "Analysis of the relationship between photosynthesis photon flux density and natural Taxus baccata seedlings occurrence," Acta oecologico, vol. 29, pp. 78-84, 2006.

[30] R. N. Melzack and D. Watts, "Cold hardiness in the yew (Taxus baccata L.) in Britain,” J. Biogeo., vol. 9, pp. 231-241, 1982.

[31] A. Dhar, H. Ruprecht and H. Vacek, "Population viability risks assessment (PVRM) for in situ management of endangered species - A case study on a Taxus baccata L. population," For. Ecol. \& Management, vol. 255, pp. 2835-2845, 2008.

[32] P. A. Thomas and J. R. Packham, "Ecology of Woodlands and Forests," Cambridge University Press, Cambridge, 2007.

[33] M. Ashmore, "Plants and pollution," in Plant Ecology, M. J. Crawley, Eds. Blackwell Science, Oxford, 1997, pp. 568-581.

[34] A. Dhar, H. Ruprecht, R. Klumpp and H. Vacek, "Stand structure and natural regeneration of English yew (Taxus baccata L.) at Stiwollgraben in Austria," Dendrobiol., vol. 56, pp. 19-26, 2006.

[35] D. Garcia, I. Martinex and J. R. Obeso, "Seed transfer among bird dispersed trees and its consequences for post-dispersal seed fate," Basic \& Applied Ecol., vol. 8, pp. 533-543, 2007.

[36] I. Martinez, D. Garcia and J. R. Obeso, "Differential seed dispersal patterns generated by a common assemblage of vertebrate frugivores in three fleshy-fruited trees," Ecosci., vol. 15, pp. 189-199, 2008.

[37] P.A. Harrison, P.M. Berry and T. E. Dawson, "Climate Change and Nature Conservation in Britain and Ireland: Modelling Natural Resource Responses to Climate Change (the MONARCH Project)," Technical Report. UK Climate Impacts Programme, Oxford, UK, 2001. 